\title{
Expanding the Domain of Policy-Relevant Scholarship in the Social Sciences
}

\author{
William Julius Wilson
}

CASEpaper 52

February 2002
Centre for Analysis of Social Exclusion

London School of Economics Houghton Street London WC2A 2AE

CASE enquiries - tel: 02079556679 


\section{Centre for Analysis of Social Exclusion}

The ESRC Research Centre for Analysis of Social Exclusion (CASE) was established in October 1997 with funding from the Economic and Social Research Council. It is located within the Suntory and Toyota International Centres for Economics and Related Disciplines (STICERD) at the London School of Economics and Political Science, and benefits from support from STICERD. It is directed by Howard Glennerster, John Hills, Kathleen Kiernan, Julian Le Grand, Anne Power and Carol Propper.

Our Discussion Paper series is available free of charge. We also produce summaries of our research in CASEbriefs, and reports from various conferences and activities in CASEreports. To subscribe to the CASEpaper series, or for further information on the work of the Centre and our seminar series, please contact the Centre Administrator, Jane Dickson, on:

$\begin{array}{ll}\text { Telephone: } & \text { UK+20 7955 6679 } \\ \text { Fax: } & \text { UK+20 7955 6951 } \\ \text { Email: } & \text { j.dickson@lse.ac.uk } \\ \text { Web site: } & \text { http://sticerd.lse.ac.uk/Case }\end{array}$

(C) William Julius Wilson

All rights reserved. Short sections of text, not to exceed two paragraphs, may be quoted without explicit permission provided that full credit, including $($ notice, is given to the source. 


\section{Editorial Note}

William Julius Wilson is the Lewis P and Linda L Geyser University Professor at the John F Kennedy School of Government, Harvard University. An earlier version of this paper was presented to a meeting of the LSE's Social Policy Department in July 2001 while he was a visitor to CASE.

\section{Abstract}

In this paper the author argues that social scientists need to do more to provide policy-relevant research. Rapid technological and economic change raise new issues about how policy should adjust that are not adequately addressed by older and narrower approaches. The author suggests two ways in which the domain of policy-relevant scholarship can be expanded. First, social scientists should be more flexible about the kinds of data they use and the ways they use them. Preliminary data can suggest new hypotheses, which can widen debate, and ethnographic and other qualitative methods can uncover patterns of behaviour invisible in quantitative sources. Second, social theories, concepts and ideas should play a greater role in the policy arena, shaping the way policy actors think about how the world works.

Keywords: social science; policy debates; research approaches.

JEL number: I00 
The 1996 Gulbenkian Commission Report on the Restructuring of the Social Sciences stated that the traditional boundaries in the social sciences have been weakened by pressures for change. ${ }^{1}$ These pressures include those stemming from the rapid expansion of the university system that increased specialisation, which in turn "encouraged reciprocal incursions by social scientists into neighbouring disciplinary domains" and those from feminist and other groups that have challenged the parochialism of the social sciences. ${ }^{2}$

In the process there has been, according to the Report, a growing recognition "that the major issues facing a complex society cannot be solved by decomposing them into small parts that seem easy to manage analytically, but rather by attempting to treat these problems, human and nature, in their complexity and interrelations."

However, the report does not discuss another major pressure felt by the social sciences that I believe will ultimately have an impact as great or even greater than those pressures that have emerged during the past several decades. I refer to the impetus to address policy-relevant issues that are associated not only with emotional and economic adjustments to the events of September 11, but, more fundamentally, those that emerge from the struggles of nation-states to adapt to the impact of rapid technological and economic changes on individuals, families, communities, institutions, and the society at large.

Technological innovations are occurring exceedingly rapidly and the lagging societal adjustment to these changes in many areas of life place strain on our basic institutions and challenge traditional practices in preparing individuals to fulfil adult roles and responsibilities. Take, for example, the impact of the decline of the mass production system. The skill requirements of this mode of production were reflected in the system of learning. Public (state) schools in the United States were principally designed to provide low-income native and immigrant students the basic literacy and numeracy skills required for routine work in mass production factories, service industries, or farms. Today's close

1 Open the Social Sciences: Report of the Gulbenkian Commission on the Restructuring of the Social Sciences. Stanford, CA: Stanford University Press, 1996.

2 Ibid.

3 Ibid. 
interaction between technology and international competition has eroded the basic institutions of the mass production system. In the last several decades almost all of the improvements in productivity have been associated with technology and human capital, thereby drastically reducing the importance of physical capital and natural resources.

Moreover, under the traditional mass production paradigm only a few highly educated professional, technical, and managerial workers were needed since most of the work "was routine and could be performed by workers who needed only basic literacy and numeracy." Accordingly, workers in the United States with limited education were able to carry home wages that were comparatively high by international and historical standards. Not so today.

At the same time that changes in technology are producing new jobs, however, they are making many others obsolete. The workplace has been revolutionised by technological changes that range from streamlined IT (information technology) to nanotechnology, robotics, and biomedical engineering. ${ }^{5}$ Since education and training are now more important than ever, the gap between the skilled and unskilled workers is widening. While educated workers benefit from the pace of technological change, lesser skilled workers face the growing threat of income stagnation and job displacement.

The impact of technological change has been intensified by international competition. In order to adjust to changing markets and technology, competitive systems are forced to become more flexible. Companies can compete more effectively in the international market either by improving efficiency, productivity, and quality or by reducing workers' income. To the detriment of the labour force, American companies tend to follow the latter course. Many new jobs have been created. However, except for the last half of the 1990s and the year 2000, incomes of lower paid workers remained stagnant, despite tremendous job growth. ${ }^{6}$

4 Ray Marshall, "School-to-Work Processes in the United States." Paper presented at the Carnegie/Johann Jacobs Foundation, November 3-5, 1994, Marbach Castle, Germany, p.4.

5 Bill Joy, “Why the future doesn't need us," Wired, April 2000, pp.238-262.

6 Ibid. 
These changes puzzle many policymakers and as they have turned to economists for some of the answers, the limitations of relying solely on a paradigm embedded in a single discipline could not be more apparent. The traditional economic models failed to explain the strange recent phenomenon of a tight labour market coexisting with low inflation in the United States. In the latter half of the 1990s into 2000, the United States experienced one of the tightest job markets in memory yet this low unemployment did not fuel inflation, and, especially prior to 1997, did not lead to significant increases in wages.

What now seems clear to an increasing number of social scientists, including economists, is that a strictly economic explanation is no longer sufficient to explain the relationship between employment and inflation. Sociological and psychological explanations about workers' responses to the growing internationalisation of economic activity, including the threat of job displacement, are now being integrated with the economic explanations. Allow me to briefly elaborate.

Between 1993 and 1997 the U.S. economy added more than 14 million jobs. And in 1997 the unemployment rate declined to 4.3 percent, the lowest in thirty years. Yet, prices did not increase very much during this period, in part because wages, the main element of costs, did not increase much either. ${ }^{7}$

Despite high levels of employment and labour shortages in some areas, workers were surprisingly hesitant to demand higher wages. Few would have predicted that kind of behaviour in such a favourable job market. As the Princeton University economist Paul Krugman pointed out in November 1997 "apparently the recession and initially jobless recovery

In addition to the stability of wages, other factors have kept prices from rising significantly. As Louis Uchitelle points out, a rise in the productivity rate since 1997 has also kept prices in check. Workers are producing more goods and services per hour on the job and the extra revenue from the sales of these "additional goods and services has helped maintain profits without price increases." He also notes that the economic crisis in Asia is helping to hold prices down "in two ways. Asian currencies are falling in relation to the dollar, making American products more expensive in those currencies. To compete, United States exporters are cutting their prices in dollars. Imports from Asia, on the other hand, are less expensive in dollars, also dampening inflation." Louis Uchitelle, "As Asia Stumbles, U.S. Stays in Economic Stride." New York Times, December 7, 1997, p.4. 
left a deep mark on the national psyche. ${ }^{\prime 8}$ He stated that workers' confidence had been shaken by downsizing and the spectre-real or imagined - that many of their jobs could be done for a fraction of their salaries by workers in Third World countries. ${ }^{9}$ Indirect evidence of workers' anxiety could be seen in the rate of voluntary resignations. Usually, when unemployment drops voluntary resignations increase because the favourable job market enables those who resign to find new jobs, presumably at higher pay. However, the "quit" rate actually declined in 1997, a period of low unemployment. ${ }^{10}$

In a 1997 survey of a random sample of the American public, 68 percent of the respondents overall and 72 percent of the non-college graduates surveyed, expressed concern about the exporting of jobs overseas by American companies. ${ }^{11}$ Reflecting on the situation in 1997, the economist Krugman argued that workers in the United States feel that they cannot rely on weak unions to bargain effectively for higher wages, and if they lose their jobs they feel compelled to take other employment soon on whatever terms they can get. "With such a nervous and timid workforce," states Krugman, "the economy can gallop along for a while without setting in motion a wage/price spiral. And so we are left with a paradox: we have more or less full employment only because individual workers do not feel secure in their jobs... The secret of our success is not productivity, but anxiety." ${ }^{\prime 12}$

In retrospect, this argument may have been overstated, especially given the rapid increase in productivity growth in the late 90 s and its dampening effect on inflation, but Krugman's line of reasoning does provide a clear example of how pressures to confront policy-relevant matters are forcing social scientists to address complex issues with explanations that integrate perspectives from different disciplines. This type of pressure contributes to the erosion of rigid disciplinary boundaries.

8 Krugman, Paul. “Superiority Complex." New Republic, November 3, 1997, p.21.

9 Krugman, op. cit.

10 Uchitelle, op. cit.

11 Alan B. Krueger, "What's Up With Wages?" Mimeo, Industrial Relations Section, Princeton University, Princeton, New Jersey, 1997.

12 Krugman, op. cit., p.22. 
But I believe that the pressure to confront policy-relevant issues will not only contribute to the integration of the social sciences, it will also increase policy-relevant research within the various disciplines. Moreover, I predict that the disciplines that most rapidly and widely respond to these pressures will attract the largest share of public and private foundation resources for research and institutional expansion. Nonetheless, there remains strong resistance to the practical application of social science research. And our vision of the domain of policyrelevant scholarship in the social sciences is limited and will have to be expanded, as I shall now endeavour to explain.

Those of us involved in policy-relevant research are fully aware of the intense pressure to address problems that concern the nation. Yet many social scientists argue that we ought to wait until a sufficient amount of good data are accumulated before we make any policy recommendations or enter the policy debate.

However, as Robert Lynd pointed out in his classic volume, Knowledge for What?, published over six decades ago, if social scientists wait for more data before offering policy recommendations, or if they avoid issues of public controversy because of lack of data even though their theoretical ideas or hypotheses would elevate the level of the debate and broaden perspectives, decisions will be made and policies will be formulated anyway-without their input. ${ }^{13}$

I fully agree and would like to take this opportunity to further challenge the assumption that the social sciences should not attempt to influence the national agenda until there are "sufficient" or "adequate" data by arguing for:

(1) a broader conception of the use and application of policyrelevant data, even preliminary data; and

(2) an increase in the role of theoretical ideas, hypotheses, and concepts in national policy debates.

Let me begin with the first point-broadening the conception of the use of policy-relevant data. Just as one will rarely find in the social sciences a data set that would unambiguously and incontrovertibly determine the

13 Robert S. Lynd. Knowledge for What? The Place of Social Science in American Culture. Princeton, NJ: Princeton University Press, 1939. 
validity of a major theory or the correctness of a major factual question, ${ }^{14}$ so too is it uncommon to produce a data set that would unambiguously and incontrovertibly resolve a public controversy. Although any social scientist would like to have the greatest confidence in his or her data, sometimes preliminary data can be used to reveal the narrowness of a public debate or to challenge the general consensus on an issue, and thereby demonstrate the need to take other factors into consideration.

For example, in the early eighties the public policy debate in the U.S. over the causes of the breakdown of the poor black family narrowly focused on the adverse effects of welfare. In a paper first presented at a national welfare conference in Virginia in December 1984, Kathryn Neckerman and I argued for the need to consider the role of male joblessness in the growth of poor single-parent African American families. ${ }^{15}$ The aggregate census-type data we presented in support of our position clearly suggested, rather than firmly established, a positive relationship between male joblessness and solo-parent families.

Nonetheless, the paper drew a lot of attention. It not only altered the terms of the debate in academic circles and triggered a round of new research among poverty researchers, but it made policymakers on Capitol Hill more aware that the issues surrounding the rapid growth of single-parent poor black families were more complex than had been previously assumed. Today male joblessness is routinely identified as one of several important factors in the growth of solo-parent families and the discussion of contributing factors no longer narrowly focuses on the receipt of welfare.

Furthermore, any discussion on the need to expand the domain of policy-relevant scholarship must address the problem of what the Harvard sociologist Stanley Lieberson calls, the "formalistic fallacy," the view that data for generating policy recommendations ought to be

14 Stanley Lieberson, "When Right Results are Wrong." Society, 26 (July / August 1989), pp.60-66.

15 William Julius Wilson and Kathryn Neckerman, "Poverty and Family Structure: The Widening Gap Between Evidence and Public Policy Issues" in Fighting Poverty: What Works and What Doesn't (Sheldon Daniziger and Daniel Wienberg, eds.). Cambridge, MA: Harvard University Press, 1986. 
obtained from the use of certain formal procedures or techniques. ${ }^{16}$ Nonquantitative research-for example, ethnographic research-is therefore considered inappropriate for generating policy recommendations.

Although all scholarly work should be subjected to critical review, concern should focus on the logic of inquiry-the structure of explanation, the significance of concepts, and the nature of evidencenot primarily on the procedures or techniques used. Let me, briefly elaborate on this point as it relates to public policy-relevant research.

Quantitative social science established its hegemony in the 1970s. Ethnographic research in fields such as urban poverty, which had been revived in the 1960s, was basically dormant in the 1970s. In the 1980s, however, we were beginning to see a shift in focus away from quantitative versus qualitative research to an approach that emphasised integrating the two strategies in empirical studies that focused on problems such as urban poverty.

There are several intellectual and practical issues involved in the integration of quantitative and qualitative techniques. These issues relate to the important distinction between the context of discovery and the context of validation. Whereas the context of discovery is concerned with the way in which fruitful concepts, hypotheses and theories are discovered, the context of validation is concerned with the evaluation of the products of science and therefore with making the evaluative criteria as explicit as possible.

I emphasise this distinction because a number of people have maintained that the best way to integrate ethnographic and quantitative research is to use the former in the context of discovery and the latter in the context of validation. In other words, it is argued that ethnography ought to be used to generate hypotheses that could then be tested with quantitative research.

More specifically, the major objection to using ethnographic research in the context of validation is the inherent difficulty in generating a sample representative of a larger population. However, there is another type of

16 Stanley Lieberson, "Einstein, Renoir and Greeley: Some Thoughts about Evidence in Sociology," American Sociological Review, 57 (February 1992), pp.1-15. 
sampling crucial to theory testing that addresses the issue of whether the conditions specified by the theoretical assumptions that guide the research are represented. This is known as theoretical sampling, defined as selecting a number of natural cases that fit the conditions appropriate to the assumptions of the theory. ${ }^{17}$

For example, in my book The Truly Disadvantaged, I outlined a theory of the social transformation of the inner city. A number of the key hypotheses incorporate the notion of "concentration effects" - the effects of living in highly concentrated poverty areas. ${ }^{18}$ One of these hypotheses states that individuals living in extreme poverty areas are much less likely to be tied into the job information network system than those living in marginal poverty areas.

I contend that this hypothesis could be tested by a participant observer who selects a neighbourhood that represents an extreme poverty area and one that represents a marginal poverty area, and who observes patterns of work-related interactions in each neighbourhood over an extended period of time. Some may question the degree of rigour involved in testing such a hypothesis with participant observation techniques, but this approach is clearly consistent with the logic of validation.

Ideally, one would want to test this hypothesis with more quantitative sources of data that would include a large number of individuals from a variety of urban neighbourhoods. But the ethnographic research, including leisurely conversations with people over extended periods of time, could uncover many subtle patterns of behaviour and experiences that are difficult, if not impossible to ascertain, with the more conventional research techniques. To eschew such research in the policy domain on formalistic grounds is to limit the potential of the social sciences to influence or contribute to important policy discussions.

However, turning to the second point-an increase in the role of theoretical ideas, hypotheses and concepts in the national debate-the contribution of the social sciences to the policy arena need not be based on empirical studies or research findings. As Carol Weiss of Harvard

17 David Willer, Scientific Sociology. New York: Prentice Hall, 1968.

18 Wilson, op. cit., 1987. 
University has pointed out, the theories, ideas, and concepts of the social sciences "may also help to shape what it is that the public thinks about and what it is that governments do." Weiss argues:

Although good data are useful and build credibility, equally important is the [social science] perspective on entities, processes, and events. Participants in the policy process can profit from an understanding of the forces and currents that shape events, and from the structures of meaning that [social scientists] derive from their theories and research. ${ }^{19}$

An important function of social science is to use existing theories or theoretical frameworks to advance our understanding of social processes or structures. In other words, social scientists can provide "enlightenment." "Sociological ideas, more than discrete pieces of data, have influenced the way that policy actors think about issues and the types of measures they have been willing to consider," states Weiss. The social sciences "bring fresh perspectives into the policy arena, new understandings of cause and effect; they challenge assumptions that have been taken for granted and give credibility to options that were viewed as beyond the pale. They provide enlightenment." Likewise, the University of Michigan political scientist John W. Kingdon points out that although social scientists "can be very good at documenting the existence, frequency, incidence, and intensity of a condition," they are also frequently "able to show policymakers that the world works in ways that might not have occurred to them," and that social scientists' knowledge of the way the world works enables them to make better cause and effect connections than others. ${ }^{21}$ For all these reasons, I believe that it would be short-sighted to discourage or overlook the use of theoretical insights from the social sciences to inform public policy debates.

19 Carol H. Weiss, "The Interaction of the Sociological Agenda and Public Policy," in Sociology and the Public Agenda (William Julius Wilson, ed.). Newbury Park: Sage Publications, 1993, p.37.

20 Morris Janowitz, "Sociological Models and Social policy," in Political Conflict: Essays in Political Sociology (Morris Janowitz, ed.). Chicago: Quadrangle Books, 1970, pp.243-59.

21 John W. Kingdon, "How Do Issues get on Public Policy Agendas?" in Sociology and the Public Agenda (William Julius Wilson, ed.). Newbury Park: Sage Publications, 1993, p.48. 
In summary, I have tried to make the case for expanding the domain of policy-relevant scholarship so that we can:

(1) be more flexible in the kinds of data that we use and the ways in which we use them, and

(2) recognise the important role of social theories, concepts and ideas in the formulation and discussion of public policy issues. I firmly believe that we will become more active and influential players in the social policy arena as a result. 